\title{
PEMAKNAAN PADA ALBUM EGO DAN FUNGSI OTAK KARYA FOURTWNTY (Kajian
}

Semiotik)

\author{
Siti Maemunah ${ }^{1}$, Nur Khasanah ${ }^{2}$ \\ ${ }^{12}$ Program Studi sastra Indonesia, Universitas Pamulang \\ dosen02349@unpam.ac.id ${ }^{1}$,nurkh253@gmail.com²
}

\begin{abstract}
ABSTRAK
Penelitian ini bertujuan untuk mendeskripsikan (1) pemaknaan denotasi yang terkandung pada lirik lagu yang terdapat dalam album Ego dan Fungsi Otak karya Fourtwnty (2) pemaknaan konotasi yang terkandung pada lirik lagu yang terdapat dalam album Ego dan Fungsi Otak karya Fourtwnty. Penelitian ini menggunakan metode penelitian kualitatif dan akan menghasilkan data secara deskriptif dengan pendekatan semiotik Roland Barthes. Adapun judul lagu dalam album Ego dan Fungsi Otak karya Fourtwnty yang dijadikan obek kajian yaitu Segelas Berdua, Kusut, Nyanyian Surau, Realita, Trilogi, Kita Pasti Tua, dan Zona Nyaman. Berdasarkan analisis data diperoleh simpulan bahwa makna denotasi dan konotasi dalam lagu berjudul Segelas Berdua terdapat 6 data, Kusut terdapat 6 data, Nyanyian Surau terdapat 6 data, Realita terdapat 5 data, Trilogi terdapat 8 data, Kita Pasti Tua terdapat 9 data denotasi serta 5 data konotasi, dan Zona Nyaman terdapat 6 data.
\end{abstract}

Kata kunci: Album Ego dan Fungsi Otak, Denotasi dan Konotasi, Semiotik

\section{PENDAHULUAN}

Musik sebagai salah satu jenis kesenian yang tetap eksis dan terus berkembang mengikuti zaman. Musik dapat digunakan sebagai sarana untuk menyampaikan pikiran dan perasaan kepada orang lain. Ungkapan pikiran tersebut diwujudkan dalam bentuk suara. Musik dalam KBBI adalah (1) ilmu atau seni menyusun nada atau suara dalam urutan, kombinasi, dan hubungan temporal untuk menghasilkan komposisi (suara) yang mempunyai kesatuan dan kesinambungan, (2) nada atau suara yang disusun sedemikian rupa sehingga mengandung irama, lagu, dan keharmonisan (terutama yang menggunakan alatalat yang dapat menghasilkan bunyi-bunyi itu).

Musik menjadi salah satu pilihan dalam pengekspresian perasaan seperti rasa sedih dan bahagia. Ungkapan tersebut dituangkan dalam bentuk kata-kata yang indah yang terdapat dalam lirik lagu. Lirik lagu digunakan untuk menyampaikan pesan yang tersusun dari kalimat-kalimat yang dapat menggambarkan suasana tertentu. Melalui lirik inilah seorang pencipta lagu dapat berkomunikasi dengan pendengarnya. Lirik menurut KBBI didefinisikan sebagai (1) karya sastra (puisi) yang berisi curahan perasaan pribadi, (2) susunana kata sebuah nyanyian. Melalui lirik inilah pencipta lagu dapat menyampaikan pesan kepada pendengarnya. Hal ini berkaitan dengan pendapat Jan Van Luxemburg (1998) yang mendefinisikan lirik merupakan teks - teks puisi tidak hanya mencakup jenis - jenis sastra melainkan juga ungkapan yang bersifat pesan iklan, pepatah, semboyan, doa-doa serta syair lagu pop.

Melalui lirik lagu seorang pencipta lagu dapat menuangkan pengalaman pribadi, pengalaman orang lain, kritikan ataupun saran seperti yang dilakukan oleh grup band Fourtwnty dalam album Ego dan Fungsi Otak. Grup band Fourtwnty merilis album Ego dan Fungsi Otak pada tahun 2018 yang terdiri dari 7 (tujuh) judul lagu yaitu Segelas Berdua, Zona Nyaman, Kusut, Nyanyian Surau, Realita, Trilogi, dan Kita Pasti Tua. Fourtwnty merupakan grup band yang tidak terlalu dominan mengangkat hal yang berhubungan dengan percintaan, melainkan lebih kepada realita sosial yang terjadi dalam masyarakat. Band fourtwnty 
yang terdiri dari 3 (tiga) personil ini menjadi salah satu bukti bahwasanya industri musik tidak harus mengangkat tema percintaan. Seperti dalam album yang berjudul "Ego dan Fungsi Otak".

Penelitian ini mengkaji mengenai makna denotasi dan makna konotasi dalam album lagu Ego dan Fungsi Otak karya Fourtwnty. Dalam album tersebut terdapat 7 lagu yang akan dikaji yaitu Segelas Berdua, Zona Nyaman, Kusut, Nyanyian Surau, Realita, Trilogi, dan Kita Pasti Tua. Untuk menganalisis lebih lanjut mengenai makna dalam album Ego dan Fungsi Otak, penulis menggunakan teori Semiotika Roland Barthes dan fokus kepada makna denotasi dan makna konotasinya. Pada dasarnya dalam hal penyampaian gagasan seseorang dapat menggunakan ungkapan denotasi dan konotasi. Denotasi digunakan untuk menyampaikan apa yang diinginkan secara langsung sedangkan konotasi digunakan untuk menyampaikan ide atau gagasan secara tidak langsung. Peneliti memilih band Fourtwnty dengan album lagu berjudul Ego dan Fungsi Otak karena dalam album ini terdapat kata atau kalimat - kalimat kiasan yang belum tentu semua orang dapat memahami maksud lagu itu sendiri.

Berdasarkan pembahasan latar belakang yang telah dijelaskan sebelumnya, penelitian ini dilakukan dengan tujuan untuk (1) Mendeskripsikan makna denotasi yang terkandung pada lirik lagu yang terdapat dalam album Ego dan Fungsi Otak karya Fourtwnty berdasarkan kajian semiotika Rolland Barthes (2) Mendeskripsikan makna konotasi yang terkandung pada lirik lagu yang terdapat dalam album Ego dan Fungsi Otak karya Fourtwnty berdasarkan kajian semiotika Rolland Barthes

\section{TEORI DAN METODOLOGI}

Metode yang digunakan dalam penelitian ini adalah metode kualitatif dan akan menghasilkan data secara deskriptif. Hal ini selaras dengan pendapat Bogdan dan Taylor (1975:5) mendefnisikan metodologi kualitatif sebagai prosedur penelitian yang menghasilkan data deskriptif berupa kata-kata tertulis atau lisan dari orang-orang dan perilaku yang dapat diamati (Samsu, S.Ag., M.Pd.I., Ph.D). Pendapat lain disampaikan oleh Subroto (2007: 8) dan Moleong (1988: 2) yang menyatakan bahwa pendekatan kualitatif menghasilkan penelitian yang bersifat deskriptif. Penelitian yang bersifat deskriptif dihasilkan dari data alamiah. Data yang dimaksud adalah data yang apa adanya dan bersifat aktual, dan dikaji menggunakan pendekatan kualitatif agar menghasilkan data yang deskriptif.

Data penelitian ini dikumpulkan menggunakan metode dokumentasi dan metode simak kemudian dilanjutkan dengan teknik simak catat. Metode dokumentasi adalah proses pengumpilan data yang bersumber dari dokumen - dokumen atau dalam bentuk rekaman (Suwendra, 2018:65). Sumber data untuk mendukung objek penelitian penulis dapatkan dari mendengarkan mp3 serta video-video yang berhubungan dengan grup band Fourtwnty yang diperoleh melalui internet seperti blog dan situs Youtube. Selanjutnya penulis menggunakan metode simak dan teknik catat sebagai teknik lanjutannya. Adapun hasil dari mendengarkan lagu dalam album Ego dan Fungsi Otak karya Fourtwnty yang telah ditransliterasikan ke dalam bentuk tulisan. Kemudian peneliti menggunakan teknik catat untuk mencatat data - data yang telah diperoleh berupa kata - kata yang mengandung makna denotasi dan makna konotasi. 
Teknik analisis data yang diterapkan dalam penelitian ini adalah teknik analisis dengan menggunakan semiotika Roland Barthes. Peneliti akan menjabarkan semua lagu yang terdapat dalam album Ego dan Fungsi Otak karya Fourtwnty dan kemudian peneliti akan membagi keseluruhan lirik lagu menjadi beberapa bait. Setelah mengelompokan menjadi beberapa bait peneliti akan melakukan analisis degan menggunakan teori semiotika Roland Barthes. Lebih lanjut, tahapan analisis data dalam penelitian ini yaitu (1) data yang diperoleh diklasifikasikan berdasarkan kalimat yang mengandung kalimat makna denotasi dan makna konotasi dalam setiap judul lagu (2) data yang diperoleh dideskripsikan dengan teori Roland Barthes dalam setiap judul lagu (3) Hasil pengelempokkan kemudian disimpulkan

\section{TEMUAN DAN PEMBAHASAN}

Semiotika adalah sebuah ilmu yang mengkaji mengenai tanda, tanda yang dimaksud termasuk pengertian simbol, indeks, dan ikon. Sebuah karya sastra merupakan komposisi tanda baik secara verbal maupun non verbal. Semiotika berasal dari bahasa Yunani yaitu semeion yang berarti tanda. Tanda itu sendiri dimaknai sebagai sesuatu yang dapat mewakili sesuatu atau dapat dikatakan metafora karena dalam pemakaian kata tidak mengandung arti yang sebenarnya. Kemudian proses mewakili itu dapat terjadi pada saat tanda itu ditafsirkan hubungannya dengan yang diwakilinya. Semiotika merpakan suatu ilmu atau metode analisis untuk mengkaji tanda dan makna (Sobur, 2016:15).

Tokoh yang mengembangkan teori semioika yaitu Ferdinand de Saussure (1857-1913), Charles Sander Pierce (1839-1914), Roland Barthes (1915-1980), Semiotika C.K. Ogden dan I.A. Richard, dan Semiotika Michael Riffaterre. Ferdinand de Saussure mengembangkan ilmu semiotika di Eropa dan menyebut ilmu yang dikembangkan dengan sebutan semiologi (semiology). Sedangkan Chareles Sander Pierce mengembangkan ilmu semiotika di Amerika Serikat dan menyebut ilmu yang dikembangkan dengan sebutan semiotika. Meskipun terdapat perbedaan dalam hal penyebutan istilah, namun keduanya sama-sama merujuk kepada ilmu mengenai tanda-tanda (the science of signs) tanpa adanya perbedaan yang terlalu spesifik (Budiman, 2011:13).

Teori Roland Barthes merupakan teori semiotik yang dikembangkan dari teori bahasa menurut Sasusure. Barthes mengembangkan teori semiotika ke dalam dua tahap pertandaan yaitu tingkat denotasi dan tingkat konotasi. Barthes menyebutkan bahwa denotasi menjadi konsep pada tingkat pertama. Makna denotasi menurut Barthes (1967) adalah tingkat pertandaan yang menjelaskan mengenai hubungan antara petanda dan penanda, atau antara tanda dan rujukannya yang terdapat pada realitas sehingga menghasilkan makna yang eksplisit, langsung dan pasti.

Tingkat pertandaan yang kedua yaitu konotasi. Barthes mengatakan bahwa konotasi secara topikal merupakan makna-makna yang tidak ada, baik dalam kamus maupun tata bahasa dari bahasa yang digunakan untuk menulis teks. Konotasi secara semiologi adalah makna yang bertitik pangkal pada kode (yang tidak dapat disusun kembali), artikulasi dari sebuah suara yang teranyam dalam teks. Pada intinya keberadaan makna konotasi tidak dapat dilepaskan keberadaanya dari makna denotasi. Barthes mengatakan bahwa konotasi adalah makna lapisan kedua yang implisit. Konotasi juga mengalami perluasan makna, perluasan tersebut didapat dari makna denotasi. 
Berdasarkan hasil analisis peneliti menghasilkan sejumlah temua mengenai makna denotasi dan makna konotasi yang terdapat dalam lirik lagu album Ego dan Fungsi Otak karya Fourtwnty. Dalam album tersebut, terdapat tujuh judul lagu yaitu Segelas Berdua, Kusut, Nyanyian Surau, Realita, Trilogi, Kita Pasti Tua, dan Zona Nyaman.

\title{
1. Analisis Lirik Lagu Segelas Berdua
}

Dalam lirik lagu Segelas Berdua ditemukan 6 data makna denotasi dan 6 data makna konotasi. Berikut data analisis semiotika Roland Barthes pada lirik lagu Segelas Berdua karya Fourtwnty

\section{Data 01}

\author{
Waktu itu aku bertamu \\ Menunggu dikursi kayu ibumu \\ Kembang lili tak tahu malu
}

Berada di genggam tangan kananku (Bait 1\&4)

Makna denotasi pada lirik diatas yaitu kata waktu dalam Kamus Besar Bahasa Indonesia (KBBI) berarti seluruh rangkaian saat ketika proses, perbuatan, atau keadaan berada atau berlangsung, Selanjutnya kata $a k u$ dalam lirik pertama merujuk pada seseorang. Kata bertamu berarti mengunjungi atau datang kesuatu tempat.

Selanjutnya kata menunggu dalam KBBI berarti menantikan (sesuatu yang mesti datang atau terjadi) atau menunggukan. Kata dikursi kayu berarti sebuah tempat duduk yang terbuat dari kayu. Disandingkan dengan kata ibumu berarti bahwa kursi kayu yang diduduki tamu itu milik ibu.

Kata kembang lili berarti salah satu jenis bunga yang berwarna putih dengan corak garis-garis merah yang berasal dari Jepang atau Cina. Kemudian kata malu dalam KBBI berarti segan melakukan sesuatu karena ada rasa hormat, agak takut, dan sebagainya. Apabila disandingkan dengan kata tak tahu malu yang notabennya merupakan salah satu sifat dari manusia maka kembang lili tersebut mempunyai makna yang baik bahwa kembang lili yang sedang mekar. Selanjutnya kata berada di genggam tangan kananku mempunyai makna kembang lili itu ada digengaman tangan sebelah kanan.

Makna konotasi pada bait pertama dan ke-empat yaitu kembang lili tak tahu malu, Berada di genggam tangan kananku menjadi salah satu istilah yang menandakan salah satu keromantisan dalam sebuah hubungan percintaan dalam hal ini ditandai dengan sebuah bunga yang ingin diberikan kepada kekasihnya. Kembang lili itu sendiri berari sebuah kesucian atau ketulusan.

Secara keseluruhan makn bait pertama dan ke-empat adalah seorang pria yang berkunjung ke rumah kekasihnya. Layaknya orang yang bertamu sang pria pun telah membawakan sesuatu untuk kekasihnya. Dalam hal ini adalah sebuah kembang lili. Dimana dengan membawakan sebuah kembang lili menunjukan sebuah ketulusan cinta kepada kekasihnya. Dan dengan memberikan sebuah bunga juga dapat menunjukan sebuah keromantisan. Sang pria menggenggam kembang lili itu pada tangan kanannya menandakan bahwa terdapat sebuah komitmen untuk saling setia serta tulus dalam menyayangi yang harus selalu dijaga dan dipertahankan dalam sebuah hubungan. 
Data 02

Merayu bukan gayaku

Romansaku berbeda (Bait $2 \& 5$ )

Makna denotasi pada lirik di atas yaitu kata merayu dalam KKBI berarti membujuk (memikat) dengan kata-kata manis dan sebagainya. Kemudian disandingkan dengan kata merayu bukan gayaku berarti membujuk dengan kata-kata manis atau gombalan bukan menjadi salah satu sikap atau kebiasaan dari seorang pria yang dilakukan dalam hidupnya. Selanjutnya kata romansaku berbeda berarti sebuah keromantisan yang dilakukan dengan cara yang berbeda atau berlainan.

Makna konotasi pada bait ke-dua dan lima yaitu kata merayu merupakan salah istilah yang digunakan dalam sebuah percintaan. Dalam lirik merayu bukan gayaku, romansaku berbeda berarti menggambarkan seorang pria yang menolak untuk mengungkapkan rasa cintanya dengan kata-kata gombalan. Hal ini tentu menjadi salah satu perbedaan yang terdapat dalam sebuah hubungan. Terkadang dalam sebuah hubungan seorang wanita pasti ingin sesekali dirayu atau dibujuk dengan kata-kata romantis oleh kekasihnya.

Secara keseluruhan makna bait ke-dua dan lima adalah seorang pria yang tidak biasa merayu kekasihnya dengan kata-kata gombal. Pria ini mempunyai cara tersendiri untuk mengungkapkan rasa cintanya dan itu bukan dalam bentuk gombalan. Bagi sang pria gombalan-gombalan itu tidak diperlukan dalam sebuah hubungan. Sang pria mempunyai pemikiran bahwa romantis itu tidak harus merayu dengan menggunakan kalimat gombalan.

Data 03

Segelas berdua

Berwarna merah isi dan langitnya

Dibawah aroma hamparan hijau (Bait 3\&6)

Makna denotasi pada lirik di atas yaitu kata segelas dalam KBBI berarti satu gelas, kemudian lengkapi dengan kata berdua berarti minuman dalam satu gelas yang diperuntukan untuk dua orang. Selanjutnya kata berwarna merah isi dan langitnya berarti minuman dalam gelas tersebut berwarna merah dan langit yang kemerahan.

Kata aroma dalam KBBI berarti (1) bau-bauan yang harus (yang berasal dari tumbuh-tumbuhan atau akar-akaran). Jika kata tersebut digabungkan dibawah aroma hamparan hijau berarti merujuk sebuah tempat yang banyak tumbuh-tumbuhan hijau.

Makna konotasi pada bait ke-tiga dan enam yaitu segelas berdua berwarna merah isi dan langitnya berarti minuman merah atau sebutan lain dari anggur merah atau minuman yang mengandung alkohol. Kemudian langit merah menggambarkan langit yang sedang sunset. Kata aroma hamparan hijau menggambarkan suasana perkebunann yang banyak tumbuh pohon hijau. Sehingga menciptakan suasana yang sejuk dengan udara yang segar. 
Secara keseluruhan makna pada bait ke-tiga dan enam adalah menggambarkan sepasang kekasih yang sedang menikmati segelas anggur merah. Dengan anggur merah mereka dapat lebih rileks dalam mengobrol. Dilengkapi langit yang sedang kemerahan atau sunset dan menggambarkan suasana yang sejuk karena dikelilingi pohon-pohon hijau. Suasana sejuk dengan udara yang segar inilah yang mereka rasakan sambil menikmati segelas anggur merah.

\section{Data 04}

Kembang lili tak tahu malu

Berada di genggam tangan kananku (Bait 4)

Makna denotasi pada lirik diatas yaitu kata kembang lili berarti salah salah satu jenis bunga yang berwarna putih dengan corak garis-garis merah yang berasal dari Jepang atau Cina. Kemudian kata malu dalam KBBI berarti segan melakukan sesuatu karena ada rasa hormat, agak takut, dan sebagainya. Apabila disandingkan dengan kata tak tahu malu yang notabennya merupakan salah satu sifat dari manusia maka kembang lili tersebut mempunyai makna yang baik bahwa kembang lili yang sedang mekar. Selanjutnya kata berada di genggam tangan kananku mempunyai makna kembang lili itu ada digengaman tangan sebelah kanan.

Makna konotasi pada bait ke-empat yaitu kembang lili tak tahu malu, Berada di genggam tangan kananku menjadi salah satu istilah yang menandakan salah satu keromantisan dalam sebuah hubungan percintaan dalam hal ini ditandai dengan sebuah bunga yang ingin diberikan kepada kekasihnya. Kembang lili itu sendiri menandakan sebuah kesucian atau ketulusan.

Secara keseluruhan makna bait ke-empat adalah lirik penegasan dari bait pertama lirik ke-tiga dan empat. Dalam bait empat ini menggambarkan ketulusan hati seorang pria kepada kekasihnya. Sang pria sangatlah serius dalam menjalani hubungan. Sang pria menggenggam kembang lili itu pada tangan kanannya menandakan bahwa terdapat sebuah komitmen untuk saling setia serta tulus dalam menyayangi yang harus selalu dijaga dan dipertahankan dalam sebuah hubungan. Besar harapan sang pria ini untuk selalu bersama-sama dengan kekasihnya.

Data 05

$$
\text { Segelas berdua }
$$

Berwarna merah isi dan langitnya

Dibawah aroma hamparan hijau, hijau (Bait 7)

Makna denotasi pada lirik di atas yaitu kata segelas dalam KBBI berarti satu gelas, kemudian lengkapi dengan kata berdua berarti minuman dalam satu gelas yang diperuntukan untuk dua orang. Selanjutnya kata berwarna merah isi dan langitnya berarti minuman dalam gelas tersebut berwarna merah dan langit yang kemerahan.

Kata aroma dalam KBBI berarti (1) bau-bauan yang harus (yang berasal dari tumbuh-tumbuhan atau akar-akaran). Jika kata tersebut digabungkan dibawah aroma hamparan hijau,hijau berarti 
merujuk sebuah tempat yang banyak tumbuh-tumbuhan hijau hal tersebut juga ditegaskan dengan adanya pengulangan kata hijau.

Makna konotasi pada bait ke-tujuh yaitu segelas berdua berwarna merah isi dan langitnya berarti minuman merah atau sebutan lain dari anggur merah atau minuman yang mengandung alkohol. Kemudian langit merah menggambarkan langit yang sedang sunset. Kata aroma hamparan hijau, hijau menggambarkan suasana perkebunan yang banyak tumbuh pohon-pohon hijau. Sehingga menciptakan suasana yang sejuk dengan udara yang segar.

Secara keseluruhan makna pada bait ke-tujuh adalah penegasan dari bait ke-tiga dan enam. Dalam bait ke-tujuh ini pencipta lagu benar-benar ingin menggambarkan sepasang kekasih yang sedang menikmati segelas anggur merah. Dengan anggur merah mereka dapat lebih rileks dalam mengobrol. Kemudian dalam bait tersebut digambarkan pula langit yang sedang kemerahan atau sunset serta menggambarkan suasana yang sejuk karena dikelilingi pohon-pohon hijau. Banyaknya pohon-pohon hijau yang tumbuh sehingga menciptakan suasana sejuk dengan udara yang segar. Keadaan tersebutlah yang saat ini dirasakan oleh sepasang kekasih sembari menikmati segelas anggur merah.

\section{Data 06}

$$
\begin{gathered}
\text { Hamparan hijau } \\
\text { Hamparan hijau } \\
\text { Hamparan hijau (Bait 8) }
\end{gathered}
$$

Makna denotasi pada lirik diatas yaitu kata hampar dalam KBBI berarti bentang atau buka lebar-lebar. Kemudian kata hijau dalam KBBI berarti warna yang serupa dengan warna daun pada umumnya.

Makna konotasi pada bait ke-delapan yaitu kata hamparan hijau berarti sebuah tempat yang luas yang dikelilingi banyak tanaman hijau.

Secara keseluruhan makna pada bait ke-delapan adalah menggambarkan sepasang kekasih yang sedang berada disebuah tempat yang luas yang dikelilingi banyak tanaman hijau. Kemudian terjadi dua kali pengulangan pada lirik yang menunjukan bahwa sepasang kekasih tersebut memang berada di bentangan alam yang luas dan hijau.

\section{Analisis Lirik Lagu Kusut}

Dalam lirik lagu Kusut ditemukan 6 data makna denotasi dan 6 data makna konotasi. Berikut contoh data analisis semiotika Roland Barthes pada lirik lagu Kusut karya Fourtwnty

Data 01

Tolong jauhkan nafsuku

Dari pesona hawamu

Aku terjangkit dan sakit

Terjebak di ruang sempit (Bait 1) 
Makna denotasi pada lirik diatas yaitu kata nafsu dalam KBBI berarti keinginan atau dorongan hati yang kuat. Kemudian digabungkan dengan kata lain menjadi tolong jauhkan nafsuku berarti meminta dihindarkan dari sebuah keinginan dalam hal ini hawa nafsu. Kata pesona dalam KBBI berarti daya tarik atau daya pikat. Dalam kalimat dari pesona hawamu berarti sebuah daya tarik yang ada dalam diri kekasihnya.

Selanjutnya kata sakit dalam KBBI berarti berasa tidak nyaman di tubuh. Apabila digabung menjadi aku terjangkit dan sakit berarti bahwa tokoh aku (Pria) merasa tidak nyaman pada tubuhnya. Kata terjebak berarti masuk ke perangkap. Dalam lirik terjebak diruang sempit berarti bahwa sang pria merasa seperti terjebak dalam ruangan yang kecil.

Makna konotasi pada bait pertama yaitu tolong jauhkan nafsuku berarti positif bahwa tokoh aku (Pria) yang sedang berusaha untuk menjauh dari masa lalunya yang kurang menyenangkan yang pernah dialami bersama dengan kekasihnya. Kemudian dari pesona hawamu berarti sebuah keindahan yang terdapat dalam diri seseorang dalam lirik ini merujuk pada mantan kekasihnya. Selanjutnya kata sakit merujuk pada efek negatif. Apabila disandingkan dengan aku terjangkit dan sakit berarti ada sebuah luka yang mendalam yang pernah didapatkan dari mantan kekasihnya yang masih terus membekas yang membuat hidupnya menjadi lemah. Terakhir kata terjebak merujuk pada konotasi yang kurang baik karena terjebak dalam lirik ini menggambarkan seorang pria yang selalu terbayang-banyang masa lalunya, semakin ingin melupakan kenangan itu semakin jelas tergambar dalam ingatan. Apabila digabungkan terjebak diruang sempit berarti bahwa bayangan masa lalu dengan kekasihnya selalu menyelimuti hidupnya seakan dia berada diruang yang sempit.

Secara keseluruhan makna bait pertama adalah menggambarkan seorang pria yang berusaha melupakan masa lalunya. Masa lalu yang sudah menorehkan luka pada hatinya. Namun, ditengah usahanya untuk melupakan mantan kekasihnya selalu muncul bayang-bayang masa lalunya. Hal inilah yang membuat sang pria susah untuk move on dan mencari wanita lain.

\title{
Data 02
}

\author{
Membiru indraku \\ Susah payahku melepasmu \\ Terlihat ku palsu \\ Tanpa rasamu menjamahku \\ Tanpa ragamu disampingku (Bait 2)
}

Makna denotasi pada lirik di atas yaitu kata membiru indraku berarti sebuah alat yang digunakan untuk merasa oleh tokoh aku telah berubah menjadi biru. Kalimat tersebut merupakan salah satu kalimat perumpamaan. Kemudian kata susah payah dalam KBBI berarti sangat sukar, susah dan lain sebagainya. Disandingkan dalam kalimat susah payahku melepasmu menunjukan bahwa tokoh aku kesusahan untuk melepaskan kekasihnya.Selanjutnya kata terlihat ku palsu berarti bahwa tokoh aku tampak tidak jujur. Kata menjamah dalam KBBI berarti (1) menyentuh dengan jari, meraba dan 
memegang. Terakhir kata raga dalam KBBI berarti badan atau tubuh. Dalam kalimat tanpa ragamu disampingku berarti bahwa tokoh aku kehilangan sosok kekasih yang selalu berada disampingnya.

Makna konotasi pada bait ke-dua yaitu kata membiru Indraku menjadi salah stau ungkapan konotasi yang berarti luka yang timbul karena cinta. Kemudian pada lirik terlihat ku palsu berarti negatif bahwa tokoh aku terlihat bukan menjadi dirinya yang sesungguhnya. Terakhir tanpa rasamu menjamahku, tanpa ragamu disampingku berarti bahwa tokoh aku telah kehilangan rasa kasih sayang dari kekasihnya dan tokoh aku sudah tidak menjalin hubungan dengan kekasihnya. Setelah mereka putus kekasihnya memilih untuk pergi meninggalkannya.

Secara keseluruhan makna pada bait ke-dua adalah menceritakan tokoh aku (pria) yang hatinya terluka karena cinta. Tokoh aku berusaha untuk melupakan mantan kekasihnya yang telah menorehkan luka dalam hidupnya. Tetapi ditengah usahanya, dirinya malah merasa ada sesuatu yang hilang dalam hidupnya. Sesuatu yang hilang itu adalah kasih sayang yang pernah dia dapatkan dari kekasihnya dulu sewaktu masih menjadi sepasang kekasih. Namun kini, tokoh aku harus sadar bahwa mereka sudah berpisah dan menjalani hidup masingmasing.

\section{Analisis Lirik Lagu Nyanyian Surau}

Dalam lirik lagu Nyanyian Surau ditemukan 6 data makna denotasi dan 6 data makna konotasi. Berikut contoh data analisis semiotika Roland Barthes pada lirik lagu Nyanyian Surau karya Fourtwnty

\section{Data 01}

Transisi kata ke kata, ku mulai terbata-bata

Berjalan kemana jiwa lamaku kapan lagi bernostalgia

Kelopak mataku lelah menjabarkan arti melayang

Melanda redup tantrumku (Bait1)

Makna denotasi pada lirik diatas yaitu kata transisi dalam KBBI berarti peralihan dari keadaan (tempat, tindakan, dan sebagainya) pada yang lain. Kata terbata-bata berarti (1) ragu-ragu, bimbang, kebingungan (2) tergagap-gagap, tidak lancar berbicara. Apabila digabung dalam lirik transisi kata ke kata, ku mulai terbata-bata berarti menggambarkan sebuah keadaan dimana kita tidak lancar dalam berbicara. Kemudian kata bernostalgia dalam KBBI berarti mengingat peristiwa-peristiwa manis yang pernah dialami pada masa lalu. Dalam kalimat berjalan kemana jiwa lamaku kapan lagi bernostalgia berarti ada sebuah bayangan yang muncul mengenai peristiwa-peristiwa masa lalu.

Selanjutnya kata lelah berarti penat, letih, payah, tidak bertenaga. Kata menjabarkan berarti menerangkan (menguraikan) secara terperinci. Selanjutnya kata melayang berarti tidak menentu, tidak terarah (tentang pikiran, tembakan, perhatian, dan sebagainya). Dalam lirik kelopak mataku lelah menjabarkan arti melayang berarti menunjukan sebuah keadaan letih saat menguraikan sesuau yang tidak terarah. Kemudian kata melanda berarti mengenai. Kata redup berarti perlahan reda atau berhenti. Kata tantrum berarti kemarahan dengan amukan atau ledakan emosi yang ditimbulkan karena 
ketidakmampuan mengungkapkan keinginan atau kebutuhan dengan kata-kata. Apabila digabungkan melanda redup tantrumku berarti sebuah ledakan emosi yang perlahan mulai berhenti.

Makna konotasi pada bait pertama yaitu transisi kata ke kata, ku mulai terbata-bata berarti sebuah keadaan dimana seseorang sedang merasakan gejolak pada dirinya yang sulit untuk diutarakan. Kemudian berjalan kemana jiwa lamaku kapan lagi bernostalgia berarti dia merasakan keresahan atau sedang mencari kembali jati dirinya dengan mengingat peristiwa yang telah terjadi di masa lalu. Dia bertanya-tanya apakah perbuatan yang yang dilakukan sudah benar atau belum, apakah hubunganya dengan Tuhan sudah baik atau belom. Selanjutnya kelopak mataku lelah menjabarkan arti melayang berarti memberikan gambaran rasa lelah setelah mengingat masa lalunya yang penuh dengan cerita. Terakhir melanda redup tantrumku berarti ada rasa penyesalan, sedih, kecewa dengan perilaku yang telah dilakukan pada masa lalu.

Secara keseluruhan makna bait pertama adalah menggambarkan seseorang yang sedang mengalami gejolak pada dirinya sendiri. Gejolak yang begitu kuat sehingga sulit untuk disampaikan dengan kat-kata. Dia merasakan sebuah keresahan yang telah terjadi di masa lampau dan sedang mencari kembali jati dirinya. Ada sebuah pertanyaan besar dalam pikiranya sendiri bagaimana perilaku dia dengan orang lain apakah sudah baik atau belum, kemudian bagaimana hubungannya dengan Tuhan apakah dia sudah dijalan yang benar atau belum. Semua pertanyaan itu menjadi satu dalam otaknya sehingga membuatnya lelah. Kemudian perasaan campur aduk seperti penyesalan,sedih, dan kecewa kini mulai terasa.

\section{Data 02}

Bait ke bait mulai kurakit menari paras sakitku

Hingga sulitku berdamai dengan nalar tak terkontaminasi (Bait 2\&5)

Makna denotasi pada lirik diatas yaitu paras dalam KBBI berarti rupa muka dan wajah. Apabila digabung bait ke bait mulai kurakit menari paras sakitku berarti terdapat bait-bait yang sedang disusun dengan perasaan yang tidak nyaman. Kata berdamai berarti berbaik kembali, berhenti, dan bermusuhan. Kata nalar berarti pertimbangan mengenai baik buruk dan sebagainya dan akal budi. Dalam lirik hingga sulitku berdamai dengan nalar tak terkontaminasi berarti ada rasa sulit untuk kembali berdamai dengan logika yang sudah terkontaminasi.

Makna konotasi pada bait ke-dua dan lima yaitu bait ke bait mulai ku rakit menari paras sakitku berarti menggambarkan sebuah keadaan dimana terdapat sebuah kebahagiaan yang telah dirangkai tetapi berujung pada rasa penyesalan. Kemudian hingga suliku berdamai dengan nalar tak terkontaminasi berarti memberikan gambaran betapa sulitnya menerima kenyataan dan segala cobaan hidup dengan ikhlas. Karena dulu ia selalu meninggikan ego tanpa mempertimbangkan baik buruknya dan selalu menolak masukan dari orang lain.

Secara keseluruhan makna bait ke-dua dan lima adalah mengambarkan sebuah kebahagian seseorang yang berujung dengan rasa penyesalan. Penyesalan itu terjadi karena 
terlalu mengedepankan ego dan tidak mau menerima masukan dari orang lain. Akibatnya dia sulit untuk menerima kenyataan dan segala cobaan hidup dengan ikhlas.

\section{Analisis Lirik Lagu Realita}

Dalam lirik lagu Realita ditemukan 5 data makna denotasi dan 5 data makna konotasi. Berikut contoh data analisis semiotika Roland Barthes pada lirik lagu Realita karya Fourtwnty

\section{Data 01}

Ini bukan cerita langka

Tak sedikit orang melakukannya

Menggambar tubuhnya tubuhnya (Bait 1)

Makna denotasi pada lirik diatas yaitu kata cerita dalam KBBI berarti tuturan yang membentangkan bagaimana terjadinya suatu hal (peristiwa,kejadian, dan sebagainya). Kemudian disandingkan dalam kalimat ini bukan cerita langka berarti ada sebuah peristiwa yang sering terjadi atau sering ditemukan. Lirik selanjutnya tak sedikit orang melakukannya berarti ada beberapa orang yang melaksanakan atau mempraktikkannya. Selanjutnya menggambar berarti membuat sebuah gambar. Dalam lirik menggambar tubuhnya tubuhnya berarti sebuah kegiatan menggambar sebuah gambar yang dilakukan dibagian tubuh diri sendiri.

Makna konotasi pada bait pertama yaitu menggambar tubuhnya tubuhnya dalam lirik tersebut merujuk pada hal kurang baik yaitu dalam lirik ini berarti membuat tato di tubuhnya sendiri. Dimana mentato mempunyai efek buruk jangka panjang seperti infeksi pada kulit, reaksi alergi, dan lainnya.

Secara keseluruhan makna bait pertama adalah menggambarkan sebuah keadaan yang sering terjadi dikalangan masyarakat yaitu menggambar sesuatu pada anggota tubuhnya atau disebut sebagai tato. Peristiwa itu sering terjadi terutama dikalangan anak muda.

\section{Data 02}

$$
\begin{aligned}
& \text { Raut wajah hingga namanya } \\
& \text { Memang indah tapi apa artinya } \\
& \text { Ternyata berpisah (Bait } 2 \& 4 \text { ) }
\end{aligned}
$$

Makna denotasi pada lirik diatas yaitu kata raut wajah berarti raut muka. Dalam lirik raut wajah hingga namanya berarti membuat gambar raut muka sampai menuliskan nama sendiri. Kata indah berarti enak untuk dilihat atau dipandang.Digabungkan dengan lirik memang indah tapi apa artinya berarti sesuatu yang enak untuk dilihat tetapi tidak mempunyai makna. Terakhir kata berbisa dalam KBBI berarti sesuatu yang dapat merusak akhlak kehidupan. Apabila digabungkan ternyata berbisa berarti sesuatu yang indah ternyata dapat merusak akhlak kehidupan.

Makna konotasi pada bait ke-dua dan empat yaitu memang indah tapi apa artinya berarti sesuatu yang indah namun tidak memiliki nilai atau sia-sia begitu saja karena tidak ada keindahan yang bersifat abadi. Dalam lirik tersebut merujuk pada tato dengan motif gambar muka dan sebuah nama yang digambar pada bagian tubuhnya. Kemudian ternyata berbisa merujuk pada sesuatu yang kurang baik. Dampak yang didapat apabila seseorang membuat tato pada bagian tubuhnya salah satunya adalah mendapat pandangan 
negatif dari orang lain. Orang yang bertato kerap disebut orang yang nakal, bandel, dan akhlaknya buruk. Meskipun pada faktanya tidak sepenuhnya itu dibenarkan. Secara keseluruhan makna bait ke-dua dan empat adalah menggambarkan seorang yang sedang mentato wajah dan nama pada tubuhnya sendiri. Tetapi ada hal yang perlu diingat bahwa tidak ada sesuatu yang sifatnya abadi, begitu pula dengan tato. Tato memang akan menambah nilai keindahan tersendiri bagi orang yang menyukainya. Akan tetapi sesuatu yang menurut kita bagus belum tentu orang lain juga sependapat. Dampak negatif dari mentato salah satunya yaitu mendapat pandangan negatif dari orang lain. Ada anggapan negatif seperti orang yang bertato nakal dan buruk akhlaknya.

\title{
5. Analisis Lirik Lagu Trilogi
}

Dalam lirik lagu Trilogi ditemukan 8 data makna denotasi dan 8 data makna konotasi. Berikut contoh data analisis semiotika Roland Barthes pada lirik lagu Trilogi karya Fourtwnty.

\section{Data 01}

\author{
Mendengung gendang telingaku \\ Memecah bising kala itu \\ Terlihat jiwa-jiwa layu \\ Terlentang didepan mataku (Bait 1)
}

Makna denotasi pada lirik lagu di atas yaitu kata mendengung dalam KBBI berarti berdegung atau bergema. Kata gendang telinga berarti bagian dari telinga yang memisahkan telinga tengah dan bagian luar yang berupa selaput tipis. Kemudian kata memecah dalam KBBI berarti merusak atau mengganggu. Kata bising berarti ramai hingga menyebabkan telinga seakan-akan pekak (karena mendengar bunyi yang tidak karuan). Apabila digabungkan dalam lirik mendengung gendang telingaku, memecah bising kala itu menjelaskan kondisi telinga yang berdengung karena ada bunyi-bunyi yang tidak karuan pada saat itu.

Kata terlihat berarti tampak atau kelihatan dan kata jiwa berarti seseorang atau orang. Kemudian kata layu berarti kondisi yang lemah atau pucat. Kata terlentang berarti dalam keadaan melentang. Apabila digabungkan terlihat jiwa-jiwa layu, terlentang didepan mataku berarti tampak orang-orang dengan kondisi lemah terlihat melentang dihadapan mata.

Makna konotasi pada bait pertama yaitu jiwa-jiwa layu berarti menggambarkan kondisi seorang manusia yang tidak berdaya bahkan meninggal dunia.

Secara keseluruhan makna pada bait pertama adalah menggambarkan situasi yang ramai tidak karuan bahkan sampai terlihat orang-orang yang tidak berdaya, oarang-orang yang sudah meninggal tergeletak atau terlentang di mana-mana.

\section{Data 02}

Teror mengecamku

Teror melumpuhkanmu (Bait 2)

Makna deonotasi pada lirik di atas yaitu kata teror dalam KBBI berarti sebuah ancaman, tindakan kekerasan dan sebagainya yang sangat menakutkan. Kata mengecam dalam KBBI berarti menyelidiki (mengamat-amati) dengan teliti. Terkhir kata melumpuhkan berarti menyebabkan lumpuh (tidak bertenaga 
lagi). Apabila digabungkan dalam lirik teror mengecamku, teror melumpuhkanmu berarti ada sebuah ancaman teror yang akan dilakukan dan akan melumpuhkan siapa saja yang ada.

Makna konotasi pada bait ke-dua yaitu teror berarti sebuah ancaman yang serius yang akan dilakukan oleh tokoh aku. Kata teror di sini dapat bermakna negatif karena dapat menghilangkan nyawa dan tentunya akan merugikan banyak pihak. Kemudian teror melumpuhkanmu berarti akan banyak korban yang berjatuhan setelah aksi teror ini dilakukan.

Secara keseluruhan makna pada bait ke-dua adalah menjelaskan sebuah rencana yang akan dilakukan oleh tokoh aku yaitu teror. Objek yang akan menjadi sasaranya adalah semua oang tanpa terkecuali. Dan akan ada banyak orang yang mati akibat teror tersebut.

\section{Analisis Lirik Lagu Kita Pasti Tua}

Dalam lirik lagu Kita Pasti Tua ditemukan 9 data denotasi serta 5 data makna konotasi. Berikut contoh data analisis semiotika Roland Barthes pada lirik lagu Kita Pati Tua karya Fourtwnty

\section{Data 01}

Ini cerita ketika tulang mulai menua

Masih mungkin ada hasrat yang menggebu-gebu

Berkumpul dan bernyanyi seperti dulu (Bait 1)

Makna denotasi pada lirik lagu di atas yaitu kata cerita berarti rangakaian peristiwa yang pernah di alami atau pernah terjadi. Kata tulang mulai menua termasuk dalam ungkapan konotasi. Kemudian kata hasrat berarti sebuah keinginan atau harapan yang kuat. Dalam lirik masih mungkin ada hasrat yang menggebu-gebu berarti sebuah keinginan yang ingin dilakukan dengan penuh semangat. Terakhir lirik berkumpul dan bernyanyi seperti dulu menjawab lirik sebelumnya bahwa ada sebuah keinginan yang kuat untuk berkumpul dan bernyanyi seperti dulu.

Makna konotasi pada bait pertama yaitu tulang mulai menua berarti menggambarkan fisik orang yang sudah tua dengan keadaan yang sudah mulai melemah. Dalam lirik ini cerita ketika tulang mulai menua berarti menggambarkan sebuah peristiwa tentang orang yang mulai menua dengan fisik mulai melemah. Kemudian lirik masih mungkin ada hasrat yang menggebu-gebu berarti ada sebuah keinginan yang kuat yang ingin sekali dilakukan.

Secara keseluruhan makna pada bait pertama adalah menggambarkan keadaan seseorang yang mulai menua dengan fisik yang tidak kuat lagi layaknya masih muda. Akan tetapi terbesit sebuah harapan untuk kembali berkumpul, bersenda gura, bernyanyi ria bersama teman-teman.

Data 02

$$
\begin{aligned}
& \text { Wajah tampanku, keriput dan badanku membungkuk } \\
& \text { Rasa ingin tak percaya kini ku menua } \\
& \text { Tak menggoda layaknya saat muda (Bait } 2 \& 5 \text { ) }
\end{aligned}
$$

Makna denotasi pada lirik diatas yaitu kata wajah tampan berarti wajah yang elok atau gagah. Kata keriput berarti berkerut pada bagaian wajah. Kata badanku membungkuk berarti tubuh yang sudah tidk tegap lagi. Apabila digabungkan dalam lirik wajah tampanku, keriput dan badanku membungkuk berarti 
sebuah gambaran mengenai wajah yang awalnya elok atau gagah perlahan mulai muncul keriput dan kondisi tubuh yang mulai membungkuk. Selanjutnya rasa ingin takpercaya kini ku menua berarti perasaan tidak percaya bahwa dirinya mulai menua. Terakhir lirik tak menggoga layaknya saat muda berarti kondisi fisik yang sudah tidak menarik layaknya saat dulu muda.

Makna konotasi pada bait ke-dua dan lima yaitu wajah tampanku, keriput dan badanku membungkuk berarti sebuah konotasi yang menggambarkan keadaan seseorang yang mulai menua dengan ciri-ciri kondisi wajah yang mulai berubah dan banyak muncul keriput-keriput pada wajah. Selain itu kondisi badan yang sudah tidak tegap atau membungkuk.

Secara keseluruhan makna pada bait ke-dua dan lima adalah menggambarkan keadaan seseorang yang mulai menua yang dapat terlihat dari ciri fisiknya. Rasanya seperti tidak percaya kalau dirinya sudah tua. Dan iaberfikir bahwa dengan kondisinya yang tua ia sudah tidak menarik perhatian orang lain lagi seperti saat fisiknya masih kuat karena usianya yang masih muda.

\section{Analisis Lirik Lagu Zona Nyaman}

Dalam lirik lagu Zona Nyaman ditemukan 6 data makna denotasi dan 6 data makna konotasi. Berikut contoh data analisis semiotika Roland Barthes pada lirik lagu Zona Nyaman karya Fourtwnty

\section{Data 01}

Pagi ke pagi ku terjebak di dalam ambisi

Seperti orang-orang berdasi yang gila materi

Rasa bosan membukakan jalan mencari peran

Keluarlah dari zona nyaman (Bait 1)

Makna denotasi pada lirik lagu di atas yaitu kata pagi dalam KBBI berarti waktu setelah matahari terbit hingga menjelang siang hari. Kata terjebak berarti masuk kedalam suatu tempat atau tidak dapat bergerak. Kemudian kata ambisi berarti sebuah keinginan yang kuat. Apabila digabungkan dalam lirik pagi ke pagi ku terjebak di dalam ambisi berarti menujukan waktu pagi dimana tokoh aku yang memiliki ambisi yang kuat merasa seperti tidak dapat bergerak. Kata berdasi berarti menggunakan sebuah dasi. Dalam lirik seperti orang-orang berdasi yang gila materi berarti orang-orang memakai dasi yang mengejar materi.

Kata rasa bosan berarti sudah tidak suka lagi karena sudah terlalu sering atau banyak. Kata membukakan berasal dari kata dasar buka yang memiliki arti jarak, antara, lebar. Kata jalan memiliki arti tempat untuk lalu lintas orang. Kata mencari berarti menemukan, memperoleh sesuatu. Kata peran memiliki arti pemain atau tingkah laku yang diharapkan dimiliki seseorang. Apabila dimaknai dalam satu kalimat atau baris pada lirik rasa bosan, membukakan jalan mencari peran memiliki arti seorang yang sudah mengalami rasa jenuh dengan hal yang sering dilakukannya, sehingga ia mencari jalan atau sesuatu yang baru. Kemudian pada lirik atau baris terakhir keluarlah dari zona nyaman memiliki arti meninggalkan atau tidak melakukan sesuatu yang sudah biasa dilakukannya.

Makna konotasi pada bait pertama yaitu kata orang-orang berdasi berarti orang-orang yang biasanya kerja di kantor. Kemudian kata gila materi berarti orang yang selalu mengejar harta kekayaan. Kata 
membukakan jalan mencari peran dapat diartikan keinginan untuk mencari pekerjaan yang baru atau mencari suasana yang baru.

Secara keseluruhan makna bait pertama adalah menggambarkan aktivitas para pekerja kantoran yang mempunyai keinginan kuat untuk mengumpulkan harta kekayaan. Namun, ada fase dimana ia bosan dengan perkerjaan yang selama ini ia lakukan. Hingga terbesit untuk mencari pekerjaan baru supaya keluar dari zona nyaman (pekerjaan) yang selama ini dikerjakan. Adanya kebosanan inilah yang menjadi faktor utama untuk mencari pekerjaan yang baru. Dengan adanya suasana baru diharapkan bisa memunculkan kembali semangat dalam mengumpulkan pundi-pundi rupiah.

\title{
Data 02
}

\author{
Sembilu yang dulu \\ Biarlah berlalu \\ Bekerja bersama hati \\ Kita ini insan \\ Bukan seekor sapi (Bait 2,5,8)
}

Makna denotasi pada lirik lagu di atas yaitu kata sembilu dalam KBBI berarti kulit buluh yang tajam seperti pisau. Kata sembilu masuk dalam kategori konotasi karena dalam lirik tidak menunjukan makna yang sebenarnya. Kemudian biarlah berlalu berarti membiarkan pergi. Kata bekerja berarti melakukan suatu kegiatan atau perbuatan. Kemudian kata insan berarti seorang manusia. Dalam lirik bekerjalah bersama hati, kita ini insan bukan seekor sapi berarti dalam melakukan sutau pekerjaan harus sesuai dengan hati karena kita ini seorang manusia bukanlah binatang (sapi).

Makna konotasi pada bait ke-dua, lima, dan delapan yaitu kata sembilu berarti kisah pilu yang pernah dirasakan. Kemudian bekerja bersama hati berarti dalam melakukan pekerjaan haruslah ikhlas dan tulus dari hati. Terakhir kita ini insan bukan seekor sapi berarti sebuah kalimat pengingat bahwa kita ini manusia yang mempunyai akal pikiran bukanlah seekor binatang, bukan juga budak yang dalam berkerja dapat diperlakukan seenaknya saja atau hanya dimanfaatkan tenaga saja layaknya seekor sapi.

Secara keseluruhan makna bait ke-dua, lima dan delapan adalah menggambarkan sebuah pengalaman pahit dan menyakitkan saat bekerja di masa lalu. Adanya kegagalan tersebut tidak menjadi alasan untuk menyerah dengan keadaan. Jadikan pengalaman tersebut sebagai pembelajaran dan penambah semangat untuk kedepannya. Dalam melakukan pekerjaan harus dengan hati yang ikhlas serta hati yang tulus. Terutama dalam bidang pekerjaan kita berhak mendapat perlakuan yang manusiawi bukan seperti memperlakukan hewan.

\section{SIMPULAN}

Berdasarkan analisis yang telah dipaparkan, penelitian mengenai Pemaknaan Pada Album Ego Dan Fungsi otak karya Fourtwnty (Kajian Semiotik) menghasilkan kesimpulan sebagai berikut:

1. Makna denotasi pada lirik lagu dalam album Ego dan Fungsi Otak karya Fourtwnty yang terdiri dari tujuh lagu yaitu Segelas Berdua, Kusut, Nyanyian Surau, Realita, Trilogi, Kita Pasti Tua, dan Zona 
Nyaman. Dalam lagu Segelas Berdua ditemukan 6 data, lagu Kusut ditemukan 6 data, lagu Nyanyian Surau ditemukan 6 data, lagu Realita ditemukan 5 data, lagu Trilogi ditemukan 8 data, lagu Kita Pasti Tua ditemukan 9 data dan lagu Zona Nyaman 6 data.

2. Makna konotasi pada lirik lagu dalam album Ego dan Fungsi Otak karya Fourtwnty yang terdiri dari tujuh lagu yaitu Segelas Berdua, Kusut, Nyanyian Surau, Realita, Trilogi, Kita Pasti Tua, dan Zona Nyaman. Dalam lagu Segelas Berdua ditemukan 6 data , lagu Kusut ditemukan 6 data, lagu Nyanyian Surau ditemukan 6 data, lagu Realita ditemukan 5 data, lagu Trilogi ditemukan 8 data, lagu Kita Pasti Tua ditemukan 5 data dan lagu Zona Nyaman 6 data.

3. Alasan pendukung dilakukannya pemaknaan denotasi dan konotasi dalam lirik lagu yaitu untuk memberikan kemudahan dalam memahami makna yang terdapat dalam lirik lagu yang ingin disampaikan penulis kepada pembaca.

\section{SARAN}

Dalam penelitian ini peneliti hanya membahas mengenai makna denotasi dan makna konotasi pada album Ego dan Fungsi Otak karya Fourtwnty. Dengan demikian masih banyak album lagu lain yang dapat dianalisis. Peneliti lainnya bisa meneliti makna denotasi dan makna konotasi dengan objek yang berbeda.

Kemudian, di antara banyak teori mengenai makna denotasi dan makna konotasi, peneliti hanya mengunakan teori pemaknaan atau semiotik yang dikemukakan oleh Roland Barthes. Peneliti lainnya dapat melakukan penelitian mengenai makna denotasi dan makna konotasi berdasarkan teori selain semiotik Roland Barthes.

\section{DAFTAR PUSTAKA}

Ambarini, As.,Umaya, Nazila Maharani. 2010. Semiotika: Toeri dan Aplikasi Pada Karya Sastra. Semarang: UPGRIS PRESS.

Badan Pengembangan Bahasa dan Perbukuan. 2016. Kamus Besar Bahasa Indonesia V . Jakarta. Kementrian Pendidikan dan Kebudayaan Republik Indonesia.

Lantowa, J., Marahayu, N. M., \& Khairussibyan, M. 2017. Semiotika: Teori,Metode, dan Penerapannya dalam Penelitian Sastra. Deepublish.

Rusmini. 2017. Metode Penelitian: (Teori dan Aplikasi Penelitian Kualitatif,

Kuantitatif, Mixed Methods, serta Research \& Development). Pusat Studi Agama dan Kemasyarakatan (PUSAKA).

Sobur, Alex. 2018. Analisis Teks Media. Bandung: PT Remaja Rosdakarya.

Sudaryanto. 1993. Metode dan Aneka Teknik Analisis Bahasa. Yogyakarta: Duta Wacana University Press.

Widjono, Hs. 2012. Bahasa Indonesia. Jakarta: Grasindo. 